\title{
C-38 EXPLORATION POTENTIAL IN THE OFFSHORE MEDITERRANEAN, EGYPT - PERSPECTIVES FROM THE CONTEXT OF EGYPT'S FUTURE RESOURCES AND BUSINESS CHALLENGES
}

JOHN C. DOLSON, PAUL J. BOUCHER and MARK V. SHANN BP-Amoco, Egypt Gas Business Unit, Cairo, Egypt

\section{ABSTRACT}

Egypt has developed 15.4-17 BBOE equivalent resources in three major geological provinces in the last 100 years of exploration. Nine billion barrels have been discovered in the mature province of the Gulf of Suez, an additional 2.5 BBOE in the Western Desert and $25 \mathrm{TCF}$ (4.1 BBOE) in the onshore and offshore Mediterranean Nile Delta. Future growth potential will come primarily from deeper pool Jurassic age reservoirs in the Western Desert and from deep water exploration in the Mediterranean sea.

The Mediterranean trends offer by far the largest growth potential and may contain $65-84$ TCF of recoverable future resources. This contrasts significantly with 11-33 TCF predicted for the Western Desert and 1.5-3 BBO in the Gulf of Suez. The possible numbers of new giant fields are also highest in the Mediterranean sea. This relatively unexplored province has only 70 key exploratory wells penetrating the Pliocene section and 14 through the Serravallian (Late Miocene) strata in an area that is geographically similar to the shelf edge of the Gulf of Mexico, USA.

More remote basins in the interior of Upper Egypt and the Red Sea may hold additional resources, but remote locations and difficult seismic imaging and other technical challenges will likely prevent rapid exploration and development of the hydrocarbon resources of these basins.

This paper reviews the geological context of the Mediterranean and the challenges awaiting the industry in developing what appears to be an emerging giant petroleum province in North Africa.

\section{INTRODUCTION}

Egypt's tectono-stratigraphic history consists of eight major episodes. These are 1) Paleozoic craton 2) Jurassic through Early Cretaceous rifting 3) Mid to Late Cretaceous passive margin and transgressions 4) Syrian Arc inversion 5) Gulf of Suez rifting 6) Red Sea breakup and Nile Delta deltaic progradation 7) Messinian salinity crisis 8) Pliocene deltaic progradation. Each of these episodes has created source rock, reservoir and seal combinations which have determined the petroleum system of each major geological province.

The Western Desert is characterized by Jurassic source rocks and Jurassic, Cretaceous reservoirs capped by Oligocene and Late Cretaceous sealing shales and limestones. Multiple seals are developed vertically in the section but the petroleum system is essentially sealed beneath the Oligocene Dabaa Shales. The Syrian Arc inversion which began 84 MA and ended in Late Oligocene time caused inversion of many of these basins and synclines, creating complex migration and charge problems which have generally made Syrian arc closures poor targets. 
Deeper, relatively uninverted Jurassic rift blocks have recently proved to be significant exploration targets.

Upper Egypt interior rift basins have been discovered in 1996 which resemble interior rift sequences with related production in Sudan. These basins are filled with Jurassic age continental source rocks and, despite discovery of 28 api oils in Jurassic reservoirs, have yet failed to produce commercial hydrocarbons.

The Red Sea and Gulf of Suez basins formed in early Miocene time and have source rocks in Cretaceous through Lower Miocene strata. The plays have been dominantly structural in the Gulf of Suez, but significant potential remains in flank and basinal positions. Sub-salt seismic imaging is poor and requires extensive filtering of multiples to obtain even low quality imaging at a reservoir scale. Sub-salt seismic imaging remains the single biggest barrier to successful exploration.

The Nile Delta began prograding into the Medterranean basin in systems closely resembling today's delta by early Serravallian time as reactivation of the Syrian Arc trend shut off the Gulf of Suez rift from the Mediterranean Sea. This event caused widespread evaporite development in the Gulf of Suez/Red Sea which forms the final seals to accumulations throughout these basins. During this evaporative event in the Gulf, deltas prograded rapidly forward in the Mediterranean, forming significant reservoirs to accumulations which are continuing to be charged from Jurassic through Miocene age source rocks today.

The proven Mediterranean trends consist essentially of 1) Oligocene through Tortonian deep water turbidites on structural closure 2) Late Tortonian and Messinian canyon fills and deltaic sandstones in stratigraphic, combination and structural traps 3) Pliocene deep water canyon fill traps 4) Pliocene growth fault traps. Future potential will be found in extension of these plays and concepts into deep water, as well as development of a huge offshore block currently held by Shell/Exxon in the ultra-deep water, where a multitude of turbidite fan, rotated fault blocks, turtle structures and levee/channel system traps exist.

\section{Mediterranean Petroleum System}

The stratal architecture of Tertiary reservoirs in the Nile Delta is controlled by fundamental underlying structural grains inherited from Jurassic, Cretaceous and Syrian Arc structural events. The Cretaceous shelf edge is commonly referred to as the "hingeline" across Northern Egypt. The east-west oriented hingeline is intersected by the Rosetta and Pelusium line fault trends, both of which trend northeast-southwest. These systems represent major tectonic boundaries.

Jurassic and Cretaceous sequences aggrade vertically along the hingeline with very little seaward progradation. In the vicinity of the Pelusium line, Syrian Arc structuration has inverted and destroyed much of the Cretaceous shelf edge. In these areas, Oligo-Miocene sedimentation is strongly controlled by underlying Syrian Arc structures and input points of reservoirs in the basin are directly often through Syrian Arc synclines and transfer zones. Regional basinward tilt of Syrian Arc structures exposed much of the northern Egyptian coastline and incisions into the Cretaceous as deep as 1500 meters occurred locally along the shelf edge.

In the Central Nile Delta, Syrian Arc deformation is slight, but the shelf edge is oversteepened. A pattern of Cretaceous and Jurassic deep water slump facies characterizes the shelf edge and, by early Oligocene time, growth faults were developed seaward of the hingeline in Oligocene strata, with growth continuing into the late Tortonian.

West of the Rosetta fault, the shelf edge is relatively undisturbed, but Cretaceous strata may reach $10,000+$ meters depth in the Herodotus basin. Gravity and magnetic data suggest this area is underlain by oceanic crust. 
Oligocene deltas were best developed southwest of the current Nile Delta, but by early Miocene time, the modern Nile Delta began to form, shedding large volumes of sediment basinward as the Gulf of Suez rift shoulders began to divert drainage back to the west and a more northward flow developed in the Nile river. Serravallian and Tortonian deep water sandstones form significant reservoirs in the giant Temsah and Akhen fields and additional deep potential exists throughout the basin.

The Messinian crisis began 8.0 MA and persisted until a major Pliocene flooding event at 5.0 MA. This is a major tectonic event during which the Straits of Gibraltar closed and widespread evaporative drawdown occurred in the Mediterranean Sea. Messinian canyons exceed 1500 meters deep in places and are beveled into uplifted structural blocks such as the Baltim/Abu Madi field trend. Hydrocarbons are trapped on subtle combination and stratigraphic traps within estuarine valley fills.

Since the onset of the Pliocene, up to 19 sequences have been developed as the Nile prograded seaward to its present position. Production has been established into the Pliocene in a wide variety of traps. The direct hydrocarbon detection made possible by seismic amplitude detection has initiated an active play in Pliocene strata in the delta which has added significant reserves.

The wide variety of play types, abundant charge and multi-storied pays make the Mediterranean Sea an attractive exploration area. Challenges to capturing future reserves remain 1) economic limits on deep water gas prospects 2) locating potential oil on the rim of the delta 3) sub-salt seismic imaging in poor data quality areas 4) looking for pressure regression trends in overpressured shales 5) avoiding shallow hazards in deep water and 6) developing adequate markets for future gas export. 